DOI: 10.20472/TEC.2018.005.002

\author{
KANRAWEE BUSAYANON \\ Faculty of Education, Ramkhamhaeng University, Thailand
}

\title{
A NEW 21ST CENTURY CLASSROOM MANAGEMENT MODEL FOR PRE-SERVICE SOCIAL STUDIES TEACHER DEVELOPMENT
}

\begin{abstract}
:
A new five-step model consisting of simulation, learning process activation through brain-based learning approach, instructional design through active learning approach, knowledge sharing under coaching, and reflective thinking was systematically developed and proposed to enhance classroom management skills in 21st century. Seventy-two pre-service social studies teachers in Thailand were selected through the purposive sampling method. The single-group interrupted time-series design was employed during the implementation of the proposed model. Data were analyzed using basic statistical methods such as means and standard deviation to examine the pre-service teachers' happiness in learning, and one-way repeated measures ANOVA to examine learning achievement, and classroom management skills in 21 st century. The results revealed that after participating in the study, the pre-service teacher had higher learning achievement and classroom management skills at the same statistical significance level of .01. In addition, they were happy in a course with the implementation of the systematically developed model.
\end{abstract}

\section{Keywords:}

Classroom management in 21st century, pre-service teacher, religion and culture.

JEL Classification: 129, 123 


\section{Introduction}

Classroom management skills are one of the most important skills of teachers to promote student academic achievements by providing safe and convenient learning environments. The management skills before $21^{\text {st }}$ century aimed for behavior control of students in the classroom. However, the classroom management in the $21^{\text {st }}$ century includes suitable learning process as well as controlling some students' behaviors which might not be suitable for them (Brophy, 2006).

The classroom management consists of various sciences which help manage situations occurring in the classroom, such as competitive situation, etc., Furthermore, the classroom management is considered as a major process for developing learners. It has a variety of aspects the pre-service students have to perceive in order to gain confidence through the learning management in the future. In addition, the pre-service students should be capable of applying and integrating all management skills. Nowadays, the classroom management skills are wrongly conceived as the skills the pre-service students are able to master and practice only in real classroom settings. In addition, Jones (2006) pointed out that forty percent of the new teachers made a decision to resign from a teaching profession during the first 5 years of their teaching because most of them had difficulties in coping with the students' behaviors.

Atay (2007) conducted an interview and a focus group to investigate the pre-service students' learning achievement and confidence in their classroom management skills. The findings revealed that that having interaction during the time of learning could build, classroom management, and during the learning time which would increasingly affect the teaching efficiency of the pre-service teachers.

Nonetheless, the problem about the strategic application of the classroom management skills usually occurs with anyone who is starting to become a teacher (McCormack, 2001). These problems were concerned as a major problem of the pre-service students who were not ready for teaching in the future (Jones, 2006). Atici's study (2007) on the causes of students' anxiety in Canada revealed that the pre-service teachers accepted that they were required to be self- developed and self-confident of teaching in order to use in the classroom management for reaching efficiency.

Learning management in Teaching Behavior in Social Studies subject is a study about instructional theories, learning management methods, learning management models, and learning management techniques on Social Studies subject, learning materials, learning evaluation, learning management by student-centered, contents integration in the learning departments, learning design and experiencing, remedial class, instructional problems, learning management plan and activities by participation. The aforementioned knowledge and skills are integrated in the study which provides the preservice teachers with authentic experiences. 
Consequently, the learners have to acquire both classroom management knowledge and skills which have to be used in the learning management. These are considered as crucial factors which enable them to reach success in classroom management. It is important to note that the pre-service teachers who possess instructional classroom management techniques and skills to increase strategies will get further benefits (Atay, 2007).

The proposed model aimed at promoting the classroom management skills in the $21^{\text {st }}$ century is conducted on the principle of brain-based learning concept, and proactive learning process and cognitive coaching to help the students develop their learning as well as classroom management skills in the $21^{\text {st }}$ century. Various activities are systematically organized by the practice process through the proactive learning process and cognitive coaching in order to create the classroom management experiences and focus on the knowledge development by brain-based learning activities. The activities employed in the study challenge the pre-service teachers to seek knowledge on more difficult contents and be able to apply that knowledge to improve and change themselves in all knowledge, attitude, feeling, perception, and classroom management in the future.

As a result, the researcher would like to employ the new learning model to promote the pre-service Social Studies teachers' learning achievement, classroom management skills in the $21^{\text {st }}$ century, and happiness in Teaching Behavior in Social Studies 2 class.

\section{Objectives}

1. To develop the instructional model to promote the classroom management skills in the $21^{\text {st }}$ century of the pre-service Social Studies teachers

2. To examine the efficiency of the developed instructional model by analyzing the results of the pre-service Social Studies teachers' learning achievement, classroom management skills in the $21^{\text {st }}$ century, and happiness in Teaching Behavior in Social Studies 2 class

\section{Research Hypothesis}

1. The pre-service teachers obtain higher learning achievement and classroom management skills in the $21^{\text {st }}$ century after participating in the study.

2. The average score of the pre-service teachers' happiness is at a high level.

\section{Research Scopes}

1. The sample in this research is undergraduate students, majoring in Social Studies, Ramkhamhaeng University, who enrolled in CSO4102 Course, Teaching Behavior in Social Studies subject 2 in the second semester of academic year 2017 (2/2017). 
2. Two types of research variables include:

2.1 Independent Variable - instructional model promoting learning management skills in the $21^{\text {st }}$ century;

2.2 Dependent Variable - three types as follows:

2.2.1 The learning achievement of CSO 4102 Course, Teaching Behavior in Social Studies subject 2;

2.2.2 Classroom management skills in the $21^{\text {st }}$ century;

\subsubsection{Happiness}

\section{Expected Benefits}

1. The proposed instructional model can be used to promote the classroom management skills in the $21^{\text {st }}$ century;

2. The research results can be used as a guideline for interested persons to apply the learning management skills to promote the classroom management skills in $21^{\mathrm{st}}$ century in the learning management of other departments; and

3. The study can shed some light on the classroom management skill development for the institutes to be able to produce the graduates to be concordant with the Thai Qualifications Framework for Higher Education B.E.2552 (2009).

\section{Research Instruments}

1. The quality of five-step models developed to promote the $21^{\text {st }}$ century classroom management was investigated in terms of content validity and objectivity by 5 specialists who completed the Index of Item-Objective Congruence (IOC) form. The plan was modified based upon the specialists' recommendations;

2. The learning achievement test is the test with the subjective test including 4 items. The two specialists were involved to investigate the concordance. The test had the difficulty index $(p)$ between 0.41 and 0.43 , the discrimination ( $r$ )was between 0.59 and 0.75 , and reliability (KR-20), and the achievement test of subjective test valued 0.62 ;

3. The evaluation model of classroom management skills in the $21^{\text {st }}$ century. The model used the evaluation criteria of the analytical scoring rubric of 4 sides. The researcher used the method of investigation on Criterion-Related Validity by using 2 specialists as criteria (Suvimon. W, 2546 ), toinvestigatethe concordance ofthe evaluationmodel.The evaluation model of classroom management skills in 
the $21^{\text {st }}$ centuryhad the Difficulty Index (p)between 0.61 and 0.72 , the Discrimination ( $r$ ) was between 0.56 and 0.81 , and Reliability (KR-20) of the measurement model of classroom management skills in the $21^{\text {st }}$ centuryhad the value of 0.58 .

4. The quality of twenty-item questionnaire for measuring the participants' happiness was investigated by three specialists. They were required to complete a fivescale evaluation form and the Index of congruence. Afterwards, the questionnaire was tried out with the non-sample group for 30 participants. The results revealed that all twenty items on the questionnaire for measuring the happiness passed the criteria and could be employed in the main study. The Discrimination ( $r$ ) was between 0.45 and 0.83 , and the reliability by using the $\alpha$-Coefficient, the happiness behavior questionnaires of Teaching Behavior in Social Studies subject2 had a value of 0.93.

\section{Data Collection}

This research used the experimental design of Single-group interrupted Time-series Design by implementing 10 learning management models of 40 hours to the graduate students, Ramkhamhaeng University registered in the CSO4102 Course of Teaching Behavior in Social Studies 2. The researcher conducted the test to measure the learning achievement and the model of classroom management skills in the $21^{\text {st }}$ centuryto try out the data collection with the non-sample students, During the test, the researcher employed the model of classroom management skills in the $21^{\text {st }}$ century to collect the data with the sample group of students, and post-test, the researcher conducted the learning achievement test, instructional model of classroom management skills in the $21^{\text {st }}$ century, and happiness behavior model, to collect the data with the sample group of students.

\section{Data Collection}

The researcher analyzed the data according to the objectives of the research as follows:

1) The results of using the instructional model promoting the classroom management skills in the $21^{\text {st }}$ century toward the learning achievementwere compared before and after studying of the sample group by analyzing the model using the Pair t-test;

2) The classroom management skills in the $21^{\text {st }}$ century of the sample group who got the instructional model promoting the classroom management skills were analyzed by using the Repeated measure ANOVA;

3 ) The happiness behavior results were analyzed to find the Mean and Standard Deviation. 


\section{Research Results}

Table 1 Comparison of the learning achievement of the students majoring in Social Studies Subject before and after learning

\begin{tabular}{l|l|l|l|l|l}
\hline \hline Learning Achievement & $M$ & $S D$ & $\mathrm{t}$ & $\mathrm{df}$ & $\mathrm{p}$ \\
\hline Before studying & 21.17 & 2.89 & 37.875 & 63 & $.000^{*}$ \\
After studying & 31.76 & 3.53 & & & \\
\hline \hline
\end{tabular}

$\mathrm{n}=64, \mathrm{k}=53,{ }^{\star} \mathrm{p}<.05$

According to Table 1, the analysis of the learning achievement for the students majoring in Social Studies Subject, it was found that the students majoring in Social Studies Subject got the learning management by the instructional model promoting the classroom management skills in the $21^{\text {st }}$ century and they had higher learning achievement after studying than before studying by statistical significance at .05 level ( $t$ $=37.875, \mathrm{df}=63, \mathrm{p}=.000$ ).

Table 2 Mean, Standard Deviation,Percentage level of the classroom management skills in the $21^{\text {st }}$ century in the $1^{\text {st }}-5^{\text {th }}$ Test

\begin{tabular}{|c|c|c|c|c|c|c|}
\hline \multicolumn{2}{|c|}{$\begin{array}{l}\text { Classroom management } \\
\text { in the } 21^{\text {st }} \text { century }\end{array}$} & $\begin{array}{l}\text { Learning } \\
\text { management } \\
\text { Aspect }\end{array}$ & $\begin{array}{l}\text { Environmental } \\
\text { management } \\
\text { Aspect }\end{array}$ & $\begin{array}{l}\text { Interaction } \\
\text { Aspect }\end{array}$ & $\begin{array}{c}\text { Teaching } \\
\text { Materials } \\
\text { Aspect }\end{array}$ & Total \\
\hline $\begin{array}{c}1^{1 \text { st }} \text { Test } \\
\mathrm{n}=64, \mathrm{k}= \\
12\end{array}$ & $\begin{array}{l}M \\
\text { SD } \\
\text { Percentage } \\
\text { Level }\end{array}$ & $\begin{array}{c}1.32 \\
0.56 \\
\text { The least } \\
11.00\end{array}$ & $\begin{array}{c}1.37 \\
0.51 \\
\text { The least } \\
11.41\end{array}$ & $\begin{array}{c}0.98 \\
0.28 \\
\text { The least } \\
8.16\end{array}$ & $\begin{array}{c}1.21 \\
0.41 \\
\text { The least } \\
10.08\end{array}$ & $\begin{array}{c}4.90 \\
0.95 \\
\text { Moderate } \\
40.83\end{array}$ \\
\hline $\begin{array}{c}2^{\text {nd }} \text { Test } \\
\mathrm{n}=64, \mathrm{k}= \\
12\end{array}$ & $\begin{array}{l}M \\
\text { SD } \\
\text { Percentage } \\
\text { Level }\end{array}$ & $\begin{array}{c}1.57 \\
0.49 \\
\text { The least } \\
13.08\end{array}$ & $\begin{array}{c}1.53 \\
0.50 \\
\text { The least } \\
12.75\end{array}$ & $\begin{array}{c}1.45 \\
0.50 \\
\text { The least } \\
12.08\end{array}$ & $\begin{array}{c}1.56 \\
0.50 \\
\text { The least } \\
13.00\end{array}$ & $\begin{array}{c}6.12 \\
0.98 \\
\text { Moderate } \\
51.00\end{array}$ \\
\hline $\begin{array}{c}3^{\text {rd }} \text { Test } \\
\mathrm{n}=64, \mathrm{k}= \\
12\end{array}$ & $\begin{array}{l}\text { M } \\
\text { SD } \\
\text { Percentage } \\
\text { Level }\end{array}$ & $\begin{array}{c}2.10 \\
0.40 \\
\text { The least } \\
17.50\end{array}$ & $\begin{array}{c}2.17 \\
0.38 \\
\text { The least } \\
18.03\end{array}$ & $\begin{array}{c}1.82 \\
0.55 \\
\text { The least } \\
15.16\end{array}$ & $\begin{array}{c}1.98 \\
0.21 \\
\text { The least } \\
16.50\end{array}$ & $\begin{array}{c}8.09 \\
0.79 \\
\text { Much } \\
67.41\end{array}$ \\
\hline $\begin{array}{c}4^{\text {th }} \text { Test } \\
n=64, \mathrm{k}= \\
12\end{array}$ & $\begin{array}{l}M \\
\text { SD } \\
\text { Percentage } \\
\text { Level }\end{array}$ & $\begin{array}{c}2.31 \\
0.46 \\
\text { The least } \\
19.25\end{array}$ & $\begin{array}{c}2.43 \\
0.50 \\
\text { Little } \\
20.25\end{array}$ & $\begin{array}{c}2.14 \\
0.39 \\
\text { The least } \\
17.83\end{array}$ & $\begin{array}{c}2.21 \\
0.41 \\
\text { The least } \\
18.41\end{array}$ & $\begin{array}{c}9.10 \\
0.96 \\
\text { Much } \\
75.83\end{array}$ \\
\hline
\end{tabular}




\begin{tabular}{c|l|c|c|c|c|c}
\hline \hline $5^{\text {th }}$ Test & $M$ & 2.65 & 2.85 & 2.53 & 2.60 & 10.65 \\
$\mathrm{n}=64, \mathrm{k}=$ & SD & 0.47 & 0.35 & 0.50 & 0.49 & 1.33 \\
12 & Percentage & Little & Little & Little & Little & The most \\
& Level & 22.08 & 23.75 & 21.08 & 21.66 & 88.75 \\
\hline \hline
\end{tabular}

According to the analysis of classroom management skills in the $21^{\text {st }}$ century illustrated in Table 2, it was found that the participants had the classroom management skills in the $21^{\text {st }}$ century as overall from the $1^{\text {st }}$ Test at the moderate level (Mean $=4.90$; S.D. = 0.95 ), with $40.83 \%$ of the total scores. Considering each aspect, it was found that the participants' classroom management skills in the $21^{\text {st }}$ century in terms of environmental management aspect in the classroom at the least level (Mean = 1.37; S.D. $=0.51$ ), with $11.41 \%$ of the total scores, and the interaction between the learners and the teachers obtained the least level (Mean $=0.98$; S.D. $=0.28$ ), with $8.16 \%$ of the total scores.

The students majoring in Social Studies Subjecthad the classroom management skills in the $21^{\text {st }}$ century as overall from the $2^{\text {nd }}$ Test at the moderate level, by having Mean equal to 6.12 , the standard deviationequal to 0.98 (51.00\% of the total scores). When considering each aspect, it was found that the students majoring in Social Studies

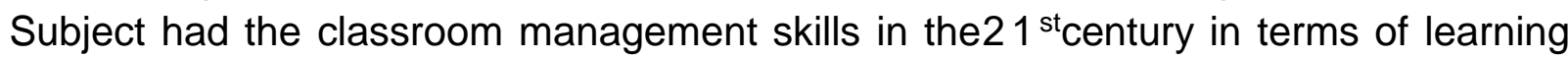
management by student centered at the least level, by having Mean at the highest level at 1.57 , the standard deviation was equal to 0.49 (13.08\% of the total scores), and had the classroom management skills in the $21^{\text {st }}$ century the least level, the interaction aspect between the learners and the teachers was at the least level as well by having Mean equal to 1.45 , the Standard Deviation at 0.50 ( $12.08 \%$ of the total scores).

The students majoring in Social Studies Subject had the classroom management skills in the $21^{\text {st }}$ century as overall from the $3^{\text {rd }}$ Test at a high level, by having Mean equal to 8.09 , the standard deviation was equal to $0.79(67.41 \%$ of the total scores).When considering each aspect, it was found that the students majoring in Social Studies Subject had the classroom management skills in the $21{ }^{\text {stcentury environmental }}$ management aspect in the classroom at the least level, by having Mean at the highest level at2.17 the standard deviation equal to $0.38(18.03 \%$ of the total scores), and had the classroom management skills in the $21^{\text {st }}$ century at the least level. The interaction aspect between the learners and the teachers was at the least level by having Mean equal to 1.82 , and the Standard Deviation was at 0.55 (15.16\% of the total scores).

The students majoring in Social Studies Subject had the classroom management skills in the $21^{\text {st }}$ century as overall from the $4^{\text {th }}$ Test, by having Mean equal to 9.10 , and the standard deviation was equal to $0.96(75.83 \%$ of the total scores).When considering each aspect, it was found that the students majoring in Social Studies Subject had the classroom management skills in the $21^{\text {st }}$ century environmental management aspect in the classroom at a little level by having Mean at the highest level at 2.43, and the 
standard deviation was equal to 0.50 (20.25\% of the total scores), and had the classroom management skills in the21st century at the least level in the interaction aspect between the learners and the teachers at the least level by having Mean equal to 2.14 , and the Standard Deviation at 0.39 ( $17.83 \%$ of the total scores).

The students majoring in Social Studies Subject had the classroom management skills in the $21^{\text {st }}$ century as overall from the $5^{\text {th }}$ Test at the highest level by having Mean equal to 10.65 , the standard deviation was equal to 1.33 ( $88.75 \%$ of the total scores). When considering each aspect, it was found that the students majoring in Social Studies

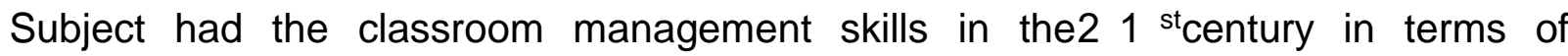
environmental management aspect in the classroom at the little level by having Mean at the highest level at2.85 the standard deviation equal to 0.35 (23.75\% of the total scores), and had the classroom management skills in the $21^{\text {st }}$ century the least. The interaction aspect between the learners and the teachers was at a little level by having Mean equal to 2.53 , and the Standard Deviation at 0.50 (21.08\% of the total scores).

Table 3 Analysis of Repeated Measure

\begin{tabular}{l|c|c|c|c}
\hline \multicolumn{1}{c|}{ Variance Sources } & SS & df & MS & F \\
\hline Between the group & 84.047 & 63 & 1.334 & \\
Within the group & 1597.200 & 214.149 & 405.424 & \\
Time & 1352.700 & 3.346 & 404.264 & $348.548^{*}$ \\
Errors & 224.500 & 210.803 & 1.160 & \\
Total & 1681.247 & 277.149 & 406.758 & \\
& & & & \\
\hline
\end{tabular}

${ }^{*} \mathrm{p}<.05$

According to Table 3, it was found that after the students majoring in Social Studies Subject got the learning management promoting the classroom management in the $21^{\text {st }}$ century, the Mean of the classroom management in the $21^{\text {st }}$ century from the Repeated Measure at least 2 periods of time and the time was different by statistical significance at .05 level $(F=348.548, d f=3.346,210.803, p=.000)$. 
Table 4The analysis of comparison of Mean for the classroom management skills in the $21^{\text {st }}$ century of the students majoring in Social Studies Subject in pairs

\begin{tabular}{|c|c|c|c|c|c|}
\hline $\begin{array}{l}\text { Classroom } \\
\text { management in the } 21^{\text {st }} \\
\text { century }\end{array}$ & $\begin{array}{l}\text { The } 1^{\text {st }} \\
\text { Test } \\
(M=4.90)\end{array}$ & $\begin{array}{l}\text { The } 2^{\text {nd }} \\
\text { Test } \\
(M= \\
6.12)\end{array}$ & $\begin{array}{l}\text { The } 3^{\text {rd }} \\
\text { Test } \\
(M= \\
8.09)\end{array}$ & $\begin{array}{l}\text { The } 4^{\text {th }} \\
\text { Test } \\
(M= \\
9.10)\end{array}$ & $\begin{array}{l}\text { The } \quad 5^{\text {th }} \\
\text { Test } \\
(M \quad M= \\
10.65)\end{array}$ \\
\hline The $1^{\text {st }}$ Test $(M=4.90)$ & - & & & & \\
\hline The $2^{\text {nd }}$ Test $(M=6.12)$ & $1.219^{*}$ & - & & & \\
\hline The $3^{\text {rd }}$ Test $(M=8.09)$ & $3.188^{*}$ & $1.969^{*}$ & - & & \\
\hline The $4^{\text {th }}$ Test $(M=9.10)$ & $4.203^{*}$ & $2.984^{*}$ & $1.016^{*}$ & - & \\
\hline The $5^{\text {th }}$ Test $(M=10.65)$ & $5.705^{*}$ & $4.531^{*}$ & $2.563^{*}$ & $1.547^{*}$ & - \\
\hline
\end{tabular}

${ }^{*} p<.05$

According to Table 4 , the analysis of comparison of the Mean for the classroom management skills in the 21st century for the students majoring in Social Studies Subject in pairs, it was found that the Mean of the classroom management skills in the $21^{\text {st }}$ century for the students majoring in Social Studies Subject after the $1^{\text {st }}, 2^{\text {nd }}, 3^{\text {rd }}, 4^{\text {th }}$, and $5^{\text {th }}$ Test was different by statistical significance at .05 level.

Table 5 The Happiness Behavior Scores of the Teaching Behavior in Social Studies subject 2 of the students majoring in Social Studies Subject

\begin{tabular}{l|l|l|l|l}
\hline \hline Item & Evaluation Items & $M$ & $S D$ & $\begin{array}{l}\text { Result } \\
\text { Interpretation }\end{array}$ \\
\hline 1 & $\begin{array}{l}\text { You feel being accepted from friends and } \\
\text { teachers. } \\
\text { You think the teachers are merciful, } \\
\text { sincere, and pay attention to the students } \\
\text { thoroughly. }\end{array}$ & 4.28 & 0.65 & Agree \\
3 & $\begin{array}{l}\text { You feel self-love and self-proud. } \\
\text { You can adjust yourself to the situation of }\end{array}$ & 4.19 & 0.47 & Strongly agree \\
4 & $\begin{array}{l}\text { learning management in various types. } \\
\text { You have an opportunity to practice and } \\
\text { do the activities in accordance with your } \\
\text { skills and interest. } \\
\text { You like the instructional contents and } \\
\text { activities in the Teaching Behavior in } \\
\text { Social Studies subject 2 }\end{array}$ & 4.25 & 0.59 & $\begin{array}{l}\text { Agree } \\
\text { You like the activities which you can }\end{array}$ \\
8 & $\begin{array}{l}\text { practice learning management skills. } \\
\text { You like the activities which } \\
\text { provideclassroom management skills. }\end{array}$ & 4.34 & 0.60 & Agree \\
\hline
\end{tabular}




\begin{tabular}{|c|c|c|c|c|}
\hline \multirow{2}{*}{9} & \multirow{3}{*}{$\begin{array}{l}\text { You realize the significance of the } \\
\text { classroom management which comes } \\
\text { from practice. } \\
\text { You like the activities promoting the } \\
\text { building of relationship skills between } \\
\text { persons and group. }\end{array}$} & \multirow{2}{*}{4.45} & \multirow{2}{*}{0.71} & \multirow{2}{*}{ Agree } \\
\hline & & & & \\
\hline 10 & & 4.44 & 0.67 & Agree \\
\hline 11 & $\begin{array}{l}\text { You like being given the opportunity to } \\
\text { share opinions. }\end{array}$ & 4.39 & 0.58 & Agree \\
\hline 12 & $\begin{array}{l}\text { You understand and realize your self- } \\
\text { esteem. }\end{array}$ & 4.41 & 0.68 & Agree \\
\hline 13 & $\begin{array}{l}\text { You discover yourself and your own } \\
\text { ability. }\end{array}$ & 4.36 & 0.65 & Agree \\
\hline 14 & $\begin{array}{l}\text { You think what you have learned can be } \\
\text { applied in the future. }\end{array}$ & 4.59 & 0.53 & Strongly agree \\
\hline 15 & You like operation in group. & 4.22 & 0.79 & Agree \\
\hline 16 & $\begin{array}{l}\text { You feel that you come to learn with } \\
\text { excitement. }\end{array}$ & 4.30 & 0.71 & Agree \\
\hline 17 & $\begin{array}{l}\text { You feel fun with the learning and would } \\
\text { like to learn. }\end{array}$ & 4.41 & 0.58 & Agree \\
\hline 18 & You determine to do your assignment. & 4.47 & 0.59 & Agree \\
\hline 19 & $\begin{array}{l}\text { You feel the atmosphere promoting } \\
\text { mutual learning. }\end{array}$ & 4.23 & 0.75 & Agree \\
\hline \multirow[t]{2}{*}{20} & You feel happy from learning. & 4.52 & 0.64 & Strongly agree \\
\hline & Total & 4.37 & 0.65 & Agree \\
\hline
\end{tabular}

According to Table 5, the happiness behavior scores of the Teaching Behavior in Social Studies subject 2 of the students majoring in Social Studies Subject, it was found that the students majoring in Social Studies were happy from learning of the Teaching Behavior in Social Studies subject 2 at a high level. $(M=4.37, S D=0.65)$.

\section{Discussion}

According to the research titled Development of Instructional Model Promoting Classroom Management Skills in $21^{\text {st }}$ century for the students majoring in Social Studies Subject, the aims were to develop the instructional model promoting the classroom management skills in the $21^{\text {st }}$ century for the students majoring in Social Studies Subject, and to study the effectiveness of the developed model, which included learning achievement of the classroom management in the $21^{\text {st }}$ century, and happiness behavior, the researcher discussed the results as follows:

1. The developed instructional model promoting the classroom management skills in the $21^{\text {st }}$ century consisted of the principles as follows: the learners participating in the instructional activities could promote their brains to work fully according to each 
individual's potentials. Moreover, the learners gained experiences by teaching processes that the teachers took on the role of coaches to make full use of the students' potentials. The instructional model promoting the classroom management skills in the21st century was conducted by the principles of the brain-based learning concepts, proactive learning processes, and cognitive coaches in order to help the learners develop their learning together with developing the classroom management skills in the $21^{\text {st }}$ century. This learning model was conducted by organizing the activities through the proactive learning process and cognitive coaches in order to create the experiences of classroom management by focusing on knowledge with the brain-based learning concept. Furthermore, five instructional steps to promoting classroom management skills in the future included: 1 . creating the simulation situation, 2 . designing the learning experiences, 3. practicing the teaching skills, 4. exchanging and learning by coaching, and 5 . reflecting the thinking.

2. The evaluation results of efficiency on the developed instructional model by trying out the instructional model revealed as follows:

2.1 The learners who used the instructional model promoting the classroom management skills in the $21^{\text {st }}$ century had higher learning achievement after learning than before learning with a statistical significance level of .01 level. The research results were in accordance with the principles used to design the learning model including the brain-based learning concept which could develop the learning achievement. Caine and Caine (2011) proposed that well-organized instructional activities could stimulate the brain to work fully with its potentials. The brain would function best when the knowledge and skills were connected with the situations. Learning could be promoted by creating a challenge of learning. This is in accordance with the proactive learning management concept. Meyers and Thomas (1993) mentioned about the proactive learning benefits that they enabled the learners to have in-depth and correct understanding of the concepts that they had learned. The proactive learning helps the learners practice the fun and challenging activities as they were provided with opportunities to create ideas on what they have practiced, solve the problems, develop their own answers, and integrate what they had learned systemically that helped them understand clearly. Various learning activities benefit them in the manner that they can apply the ability and conceptual skills as well as techniques to operate and solve the problems in real life. The proactive learning works well when there are both high and low-proficient students in the classroom. The teachers use different methods to help the students understand. In addition, peer-assisted approach or learning by friends helping friends can be employed. The high-proficient learners are assigned to explain lessons or what they learn in class to their low-proficient classmates.

2.2 The classroom management skills in the 21st century had a higher level. The research results were in accordance with the principles used to design the instructional models, i.e. proactive learning management concept. Meyers, C., \& Jones, B. Thomas. (1993) proposed that proactive learning helps the learners get benefits from 
the interaction in the classroom with friends. The learners had the opportunity to set the questions, criticize, and be admired from the classroom, develop work, present the different methods and views of each individual, as well as create challenge and motivate both learners and teachers to be fun. Furthermore, the learners developed the social experiences and learned self-learning, and be able to cooperate with others well. These affect the classroom management skills according to the concept of Brophy(2006, p. 5) which had to be able to create the appropriate environments of learning that led to successful instructional management in terms of environment, building rules and regulations as well as making the lessons be interesting continuously, as well as participating in the academic activities in the classroom. This is in accordance with the principle of cognitive coaching. Wichai, W., \& Marut, P. (2015) proposed that it was a process which helped the learners who were coached of practice learning activities to be able to achieve the goals effectively andconnect to the learning, build the opportunity for the learners to think and find out the correct answers in order to develop their own potentials. Therefore, it affects the classroom management skills in the 21 st century in terms of self-development because in the instruction the researcher has evaluated the teaching by observing and evaluating the development of the learners in various aspects which are considered as the coaching of each time to develop such skills.

2.3 The happiness behavior on Teaching Behavior in Social Studies subject 2 had the mean of the learners at a high level. This can be discussed that the instructional management by using the instructional model promoting the classroom management skills in the21st century enhanced the students to learn through practice in the classroom by the process of proactive learning, and the teachers used the coaching technique to develop the classroom management skills to help the learners create the experiences of classroom management by focusing on the knowledge development by brain-based learning. The activities which use this learning model are challengingfor the learners to seek for what is more difficult for them, be able to apply the knowledge to improve and change themselves in terms of knowledge, attitude, feeling, perception. Furthermore, the classroom managementskills can be applied to use in the future and it is in accordance with the concept of proactive learning which is able to promote the positive attitudes towards the learning. The proactive learning helps the teachers be able to adjust the students' attitudes toward the learning.Although the classroom is such a big size, the learners are still satisfied from the contents and exercises which are authentic and are relatable to their real life. Its increasing significance from the efforts and responsibilities can be seen since the learners realize the worth of learning which they are able to practice authentically. 


\section{References}

Atay, D. (2007). Beginning teacher efficacy and the practicum in an EFL context. Teacher Development, 11(2): 203-219.

Atici, M. (2007). A small-scale study on student teachers' perceptions of classroom management and methods for dealing with misbehavior. Emotional and Behavioural Difficulties, 28(1): 15-27.

Brophy, J. (2006). History of research. In E. Evertson \& C. Weinstein (Ed.), Handbook On Classroom Management, (pp. 17 - 40). New Jersey: Lawrence Erlbaum Associates.

Caine, R. and Caine, G. (2011). Natural Learning for a connected World: Education, Technology and the Human Brain. Teachers College Press

Jones, V. (2006). How do teachers learn to be effective classroom managers? In E. Evertson \& C. Weinstein (Ed.), Handbook on Classroom Management, (pp.887 - 907). New Jersey. Lawrence Erlbaum Associates.

McCormack, C. (2001). Investigating the impact of an internship on the classroom management beliefs of preservice teachers. The Professional Educator, 23(2): 11-22.

Meyers, C., \& Jones, B. Thomas. (1993). Promoting active learning (first edition ed.). San Francisco. Jossey-Bass.

Suwimon, W. (2003). Performance Testing. Bangkok: Center for Innovations Textbooks and Academic Papers Faculty of Education Chulalongkorn University [in Thai]

Wichai, W., \& Marut, P. (2015). Cognitive coaching. Bangkok: Charansanitwong Printing [in Thai] 